J. Perinat. Med. 15 (1987) 61

\title{
Low risk vaginally born preterm infants: A four year psychological and neurodevelopmental follow-up study
}

\author{
Peter Holmqvist, Christina Regefalk, and Nils W. Svenningsen
}

Department of Pediatrics, University Hospital, Lund, Sweden

\section{Introduction}

Modern perinatal care has changed the standards for preterm infant viability, morbidity and mortality developed some ten or even five years ago. Previous studies tend to focus mainly on either neurological or psychological aspects alone $[10,12,13]$. Recent studies comparing preterm infants at term conceptual age with term infants show low behavioral performance within the former group [8]. However, being born preterm today equals a period of ten weeks (26-36 weeks of gestation) compared to only six weeks (37-42 weeks of gestation) in infants born at term. Investigations of the preterm infant are thus more difficult to evaluate and can easily be misinterpreted. To avoid this problem the gestational age, i.e. very preterm vs. moderate preterm, must be considered [15, 18].

The aim of this prospective study has been to evaluate how conceptual age an fetal acidosis, correlate to the psychosocial and neurodevelopmental outcome in vaginally born low risk pregnancy preterm infants.

\section{Material and methods}

The study group is comprised of 39 preterm ( $>37$ gestational weeks) vaginally born infants who were born between January and December 1979. These pregnancies were all classified as low risk according to obstetrical standards, and high risk pregnancies were not included [24].
As a control group, ten infants born at term were followed in the same way, i.e. all infants, including control infants, were examined in a room adjacent to the delivery room during the first 45 minutes. Each baby was immediately cared for by a nurse and a neonatologist. Fetal scalp $\mathrm{pH}$ as well as acidbase data at one and twelve hours after delivery were obtained. Individual follow-up at $3,9,12,24$ and 48 months of age was carried out by a psychologist and a neonatologist. Of the 36 preterm survivors, two infants did not participate in the psychologic part at 9 and 24 months, but did participate at 48 months of age and one family had moved from our area.

The preterm infants were grouped according to gestational age, i. e. Group I, 29-33 gestational weeks, and Group II, 34-36 weeks of gestation. All complications during treatment in the neonatal ward occurred in Group I: one sepsis, one cerebral hemorrhage, one bronchopulmonary dysplasia and four patients with repeated apneas of immaturity.

At the follow-up, a semistructured interview covering socioeconomic conditions (family structure, working conditions, educational level, economic status, smoking and drinking habits, child rearing goals, methods correlated to the psychosocial status of the infant) and developmental status was carried out by the psychologist. The mothers were divided into two groups: well educated (school years $>11$ years) and less educated (school years $<11$ 
years). At nine months of age the Boel hearing and vision test, with the eyes moving towards sound, and the Catell intellectual performance and neurodevelopmental test with average range of IQ points $90-110$ were carried out [3, 20]. According to the IQ points the infants were divided into three groups: Average, above average, below average. The results of the first interview at nine months were re-evaluated at two years of age. Abnormalities were categorized depending on the type of neurological impairment found, psychomotor and neurologic or a combination. Minor neurodevelopmental disorders were transient psychomotor deviations (PMD) such as, abnormal muscular tone or behavioral status. Major neurodevelopmental disorders were psychomotor retardation (PMR) after correction for conceptual age, mental retardation or neurologic handicap (NH) such as cerebral paly or other permanent neuromuscular disorder. The Denver and Milano Comparetti $[9,16]$ were used when assessing the developmental status. Follow-up at the Child Health Care Center was then made at four years of age with a physical examination and hearing and vision tests as well as an interview covering the social and behavioral ability of the child. Parental and institutional consent were obtained for the present study.

\section{Results}

The gestational age groups and the number of infants with fetal acidosis are shown in table I. In Group I, seven of thirteen infants (52\%) had fetal acidosis $(\mathrm{pH}<7.20)$ but in Group II there were only 3 of $23(12 \%)$.
In table II (Group I) and in table III (Group II) data on each individual child as well as their mothers are presented. The acidbase balance in both fetal acidotic $(\mathrm{pH}<7.20)$ and non-acidotic $(\mathrm{pH}>7.20)$ groups had normalized within 60 minutes after birth. The five minute Apgar score was $\geqslant 7$ in all the infants. During the first week, two preterm Group I infants died: one after eight days from necrotizing enterocolitis with an accompanying intracranial bleeding, and the other child, who died suddenly and unexpectedly at home aged 198 days, had had a stormy neonatal period because of severe respiratory distress syndrome. In Group II one infant died of respiratory distress syndrome with an accompanying intracranial bleeding after three days.

In the control group all infants started to walk between 10 and 11,5 months of age; whereas, four preterm Group II infants and one Group I infant started to walk before the age of 12 months. One Group II and three Group I infants did not start walking until 18 months of age, and all of them had psychomotor deviant behavior, either at two or four years of age. Two of the late walking Group I infants also had fetal acidosis $(\mathrm{pH}<7.20)$.

The hearing and vision tests at nine months of age showed no differences between the groups (tables II, III). At four years of age, seven out of nine preterm infants admitted to the Ophthalmology Department were treated for squinting (in 2 Group I, and 2 Group II infants) and refractional problems (in 1 Group I and 2 Group II infants). Of the nine preterm infants admitted to the Otorhinalaryngology Clinic,

Table I. Surviving preterm infants of different gestational age and term control group.

\begin{tabular}{llll}
\hline & $\begin{array}{l}\text { Group I } \\
\mathbf{n}=15\end{array}$ & $\begin{array}{l}\text { Group II } \\
\mathbf{n}=24\end{array}$ & $\begin{array}{l}\text { Control } \\
\mathrm{n}=10\end{array}$ \\
\hline Gestational age (w) & $29-33$ & $34-36$ & $39-41$ \\
Survivors & $13(87 \%)$ & $23(96 \%)$ & 10 \\
Mean birth weight (g) (range) & $1995(1075-2260)$ & $2367(1510-3140)$ & $3442(2960-4200)$ \\
SGA & 1 & 4 & 0 \\
pH $<7.2$ (fetal scalp pH) & $7(52 \%)$ & $3(12 \%)$ & 0 \\
pH $>7.2$ (fetal scalp pH) & 6 & 20 & 10 \\
\hline
\end{tabular}




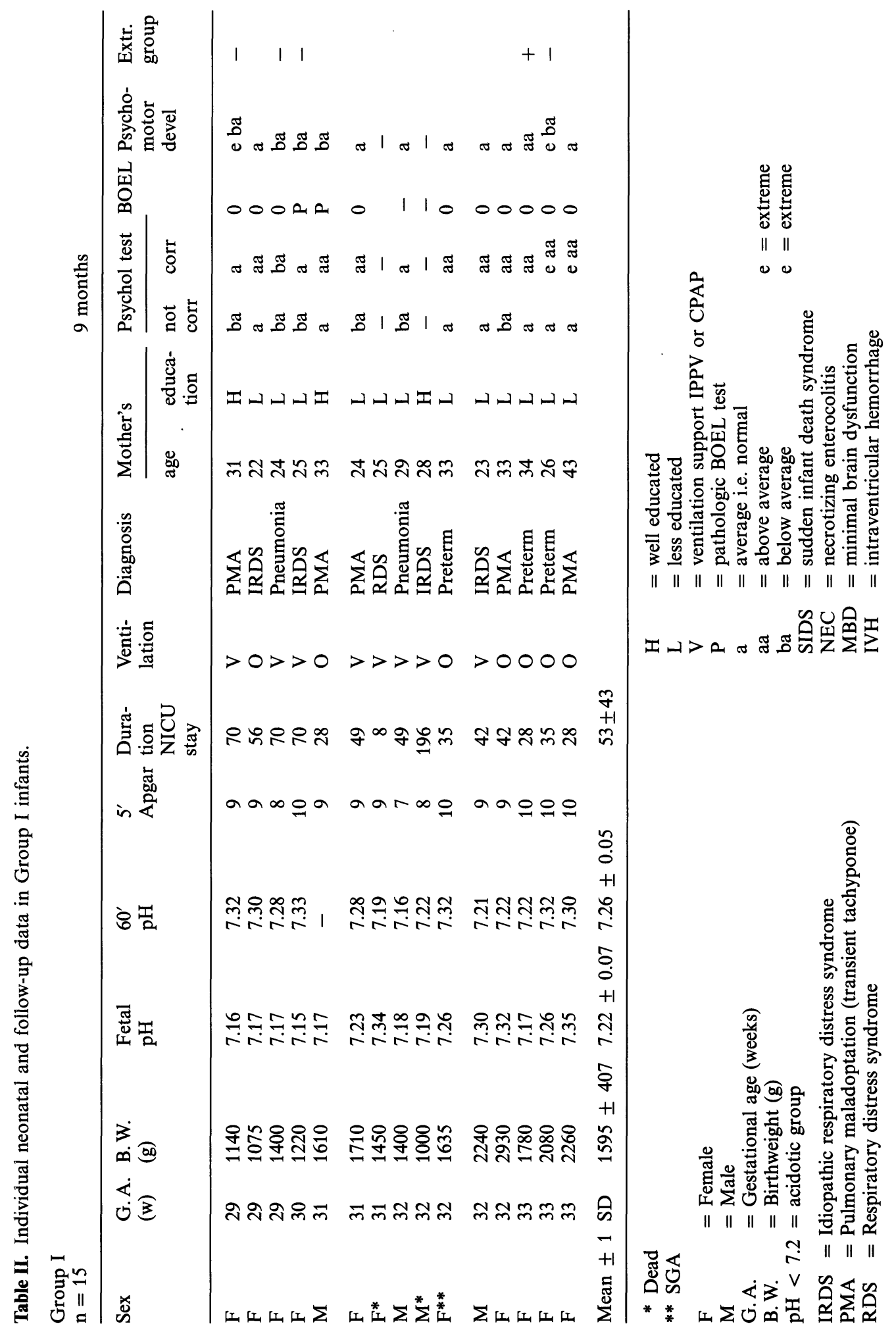




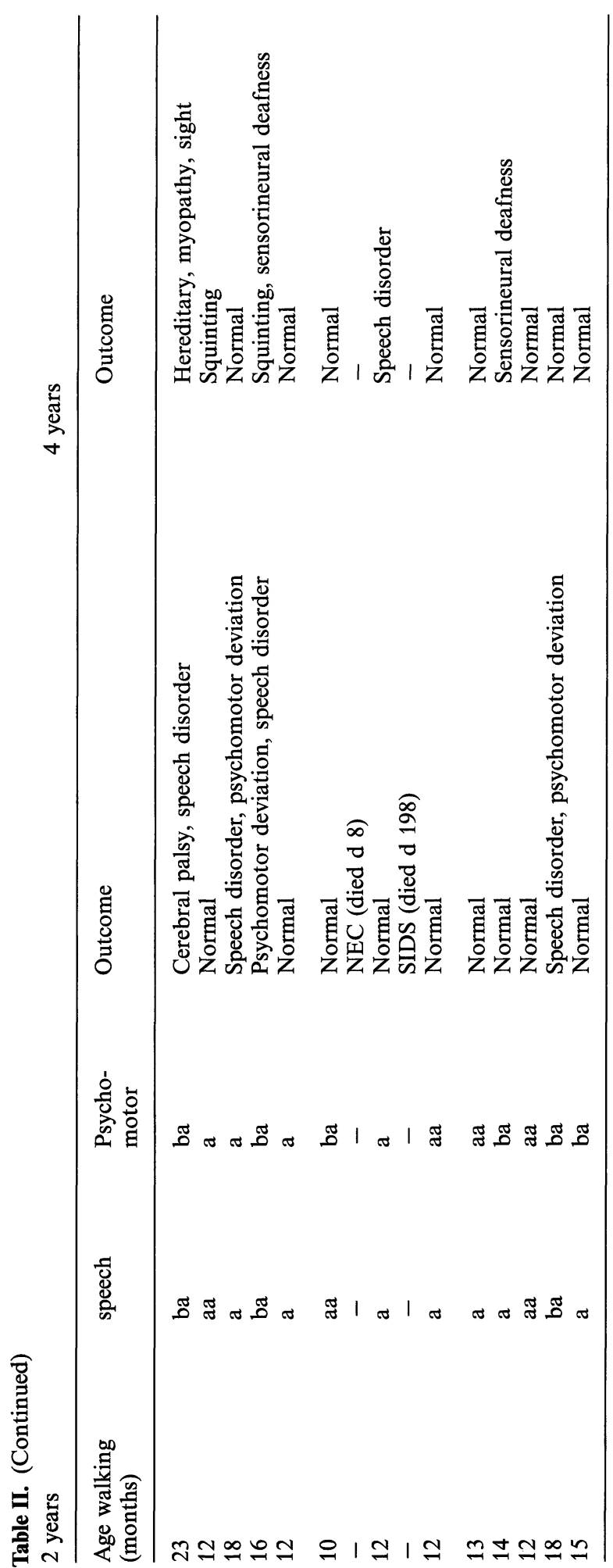

four were normal, two Group I infants had a sensorineural deafness, and four Group II infants had difficulties that needed speechdisorder support. Among term control infants no such problems were found.

The psychosocial examination made at nine months of age using the Catell test on intellectual capacity, is shown in figure 1. The test showed that the performance of four preterm infants was above average (aa), 20 infants were average (a), and nine infants scored below the average (ba). The $46.1 \%$ Group I and $14.3 \%$ Group II infants who scored below average without correction for gestational age had a normalized distribution with only $0 \%$ and $4.8 \%$ respectively below average when corrected for gestational age. The average intellectual capacity in the Catell test measured as IQ points for the preterm infants was 97 (range 64-113) and for the term control infants, 115 (range $99-123)$. When corrected for conceptual age, the preterm infants with an average IQ of 114 (range $70-133$ points) did not differ from the term infants.

Less educated mothers were found in $74.4 \%$ of the preterm group in contrast to $50.0 \%$ in the term control group. Two well educated and five less edicated mothers had infants who, at four years of age, showed psychomotor deviations. The mother of one child with a neurologic handicap belonged to the less educated group. The well educated mothers were older, and they had also married later than the less educated mothers. One mother in the preterm group was unmarried. As confirmed at subsequent interviews, the families' socioeconomic structure and interpersonal relations were stable. Over the period studied, the parents were divorced in only one preterm and in one term control family.

At the first interview in the neonatal ward, questions were adapted for the estimation of attitudes on having a preterm child. This revealed that having a preterm baby and with the child being separated from its mother, there was a more stressful experience for primigravidae mothers ( 12 preterm and 7 term); however, this was considered a minor problem, lasting only 


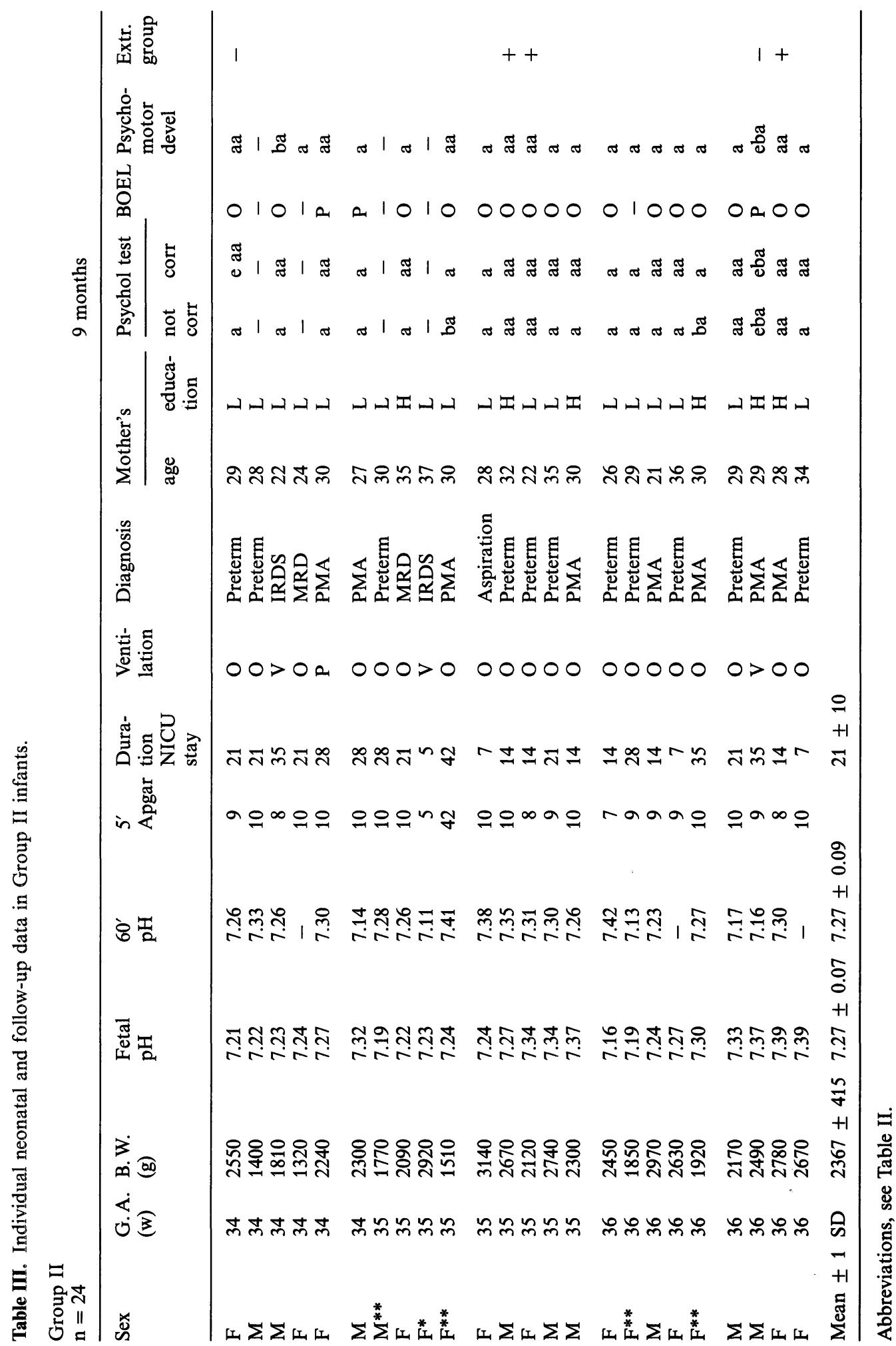




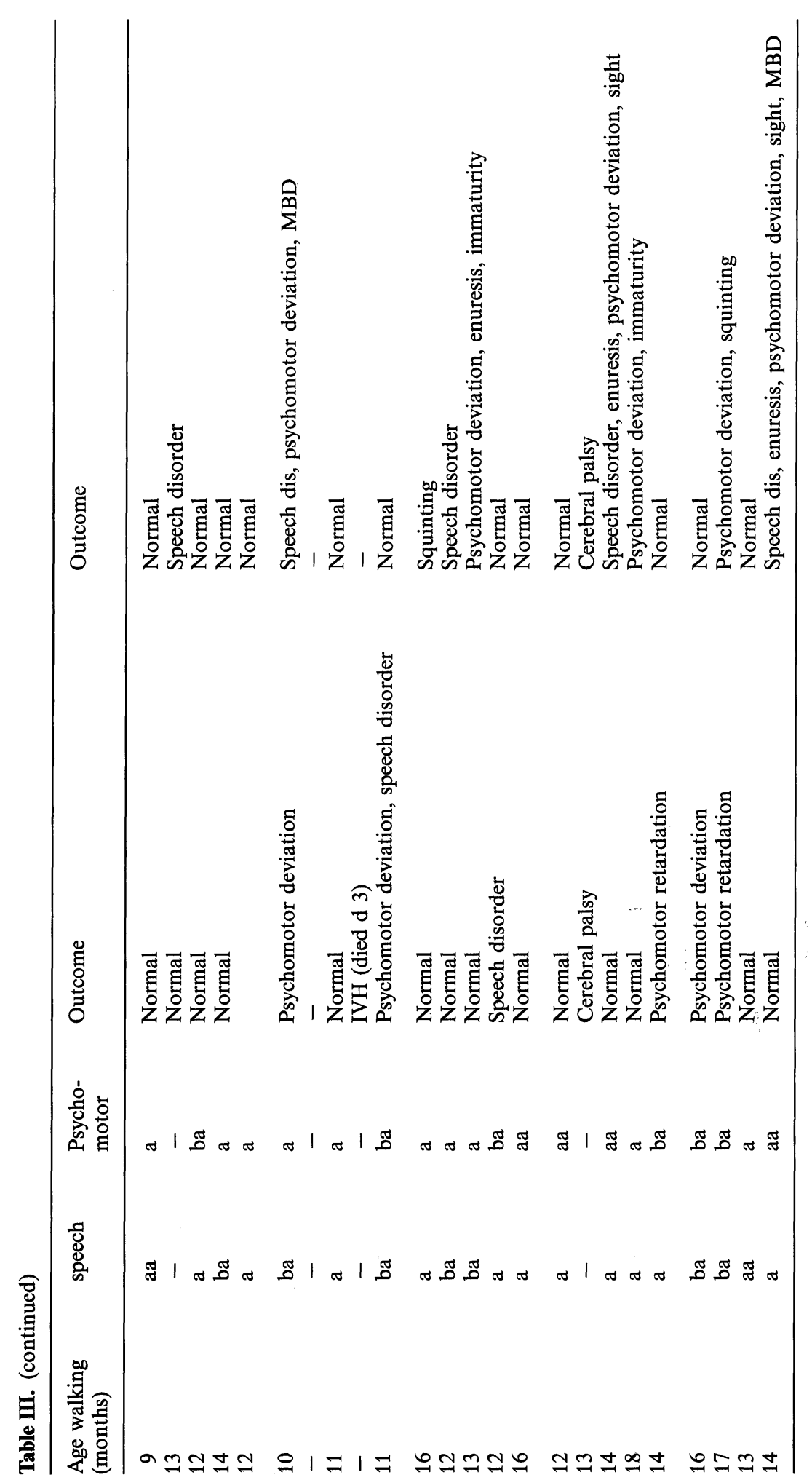

J. Perinat. Med. 15 (1987) 


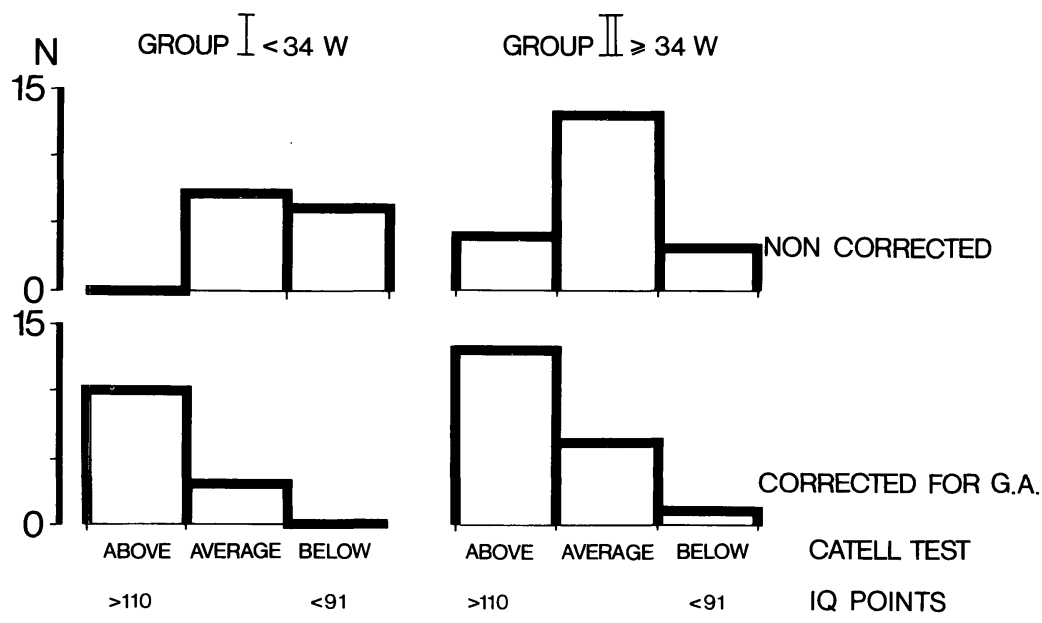

Figure 1. Intellectual performance (IQ points) with correction for conceptual age on Catell test at 9 months of age.

for the first days, when asked again at subwequent interviews. On returning home from the neonatal ward, all but two mothers reported a normal mother to infant relationship.

The psychological assessments of infants with extremely low $(-)$ or extremely high $(+)$ performance, i.e. infants showing minimum and maximum combined test results as shown in tables II and III, are summarized in table IV. In both the low and the high performance groups respectively, two and three mothers had high and low levels of educational. Fetal acidosis was present in three of five low performance infants. Two of five had normalized at four years of age.

On language performance at nine months of age (table V) the delay following prematurity, in contrast to infants born at term, was obvious. The understanding of language was good and did not differ between the two groups of infants. When speech was tested at four years of age, four Group II infants needed speech disorder help, and two Group II infants had minor speech problems with syllables as one did in the term control group.

Table IV. Extreme infants on psychological assessment.

\begin{tabular}{lllllllll}
\hline $\begin{array}{l}\text { 9-month- } \\
\text { perfor- } \\
\text { mance }\end{array}$ & $\begin{array}{l}\text { Gest. } \\
\text { group }\end{array}$ & $\begin{array}{l}\text { G. A. } \\
\text { (w) }\end{array}$ & $\begin{array}{l}\text { Fetal } \\
\text { pH }\end{array}$ & Sex & $\begin{array}{l}\text { B. W. } \\
\text { (g) }\end{array}$ & $\begin{array}{l}\text { Walking } \\
\text { age }\end{array}$ & $\begin{array}{l}\text { Late } \\
\text { speech }\end{array}$ & $\begin{array}{l}\text { Normal neuro- } \\
\text { development } \\
\text { at } 4 \text { years }\end{array}$ \\
\hline Low & I & 29 & 7.16 & girl & 1140 & 23 & yes & no \\
& I & 29 & 7.17 & girl & 1400 & 18 & no & yes \\
& I & 30 & 7.15 & girl & 1220 & 16 & yes & no \\
& I & 33 & 7.26 & girl & 2080 & 18 & yes & yes \\
& II & 36 & 7.37 & boy & 2490 & 17 & yes & no \\
High & I & 33 & 7.16 & girl & 1780 & 12 & no & yes \\
& II & 34 & 7.21 & girl & 2550 & 9 & no & yes \\
& II & 35 & 7.27 & boy & 2670 & 12 & yes & yes \\
& II & 35 & 7.34 & girl & 2120 & 13 & yes & yes \\
& II & 36 & 7.39 & girl & 2780 & 13 & no & yes \\
\hline
\end{tabular}


Table V. Language development at 9 months, 2 and 4 years of age.

\begin{tabular}{llll}
\hline & \multicolumn{2}{l}{ Preterm } & \multirow{2}{*}{ Term control } \\
\cline { 2 - 3 } & Group I & Group II & \\
\hline 9 months & $\mathrm{n}=13$ & $\mathrm{n}=20$ & $\mathrm{n}=10$ \\
Babble & 3 & 2 & 0 \\
Combine syllables & 1 & 4 & 1 \\
Understand and repeat words & 7 & 13 & 8 \\
Speaks 1-3 words & 2 & 1 & $\mathrm{n}=10$ \\
2 years & $\mathrm{n}=13$ & $\mathrm{n}=20$ & 0 \\
Combines 1-2 word, poor language & 3 & 6 & 7 \\
Combines 2-4 words & 7 & 13 & 3 \\
Combines sentences $>$ 4-5 word, good language & 3 & 1 & $\mathrm{n}=10$ \\
4 years & $\mathrm{n}=13$ & $\mathrm{n}=22$ & 1 \\
Speech disorders & 1 & 5 & 9 \\
Understand and speak well & 12 & 17 & \\
\hline
\end{tabular}

As shown in table VI the neurodevelopmental outcome at four years of age was normal in all term control infants. At three years of age, one preterm Group I infant was diagnosed as having a hereditary muscular disorder. At four years of age, four preterm infants had some form of neurologic handicap ( 3 in Group I and 1 in Group II). Unilateral otoneuropathy was found in two of the Group I infants. In six Grup II infants minor psychomotor deviations (PMD) were noted. All in all 5 infants in Group I, 9 in Group II and 1 in the control group, had squinting, hearing, speech disorders, psychomotor deviations or neurologic handicaps alone, or as additional findings.
Mostly, the psychomotor developmental (PMD) problems seemed to be of minor importance, and the number changed from time to time, as seen in figure 2. The rate of PMD found in Group I and Group II infants, showed a tendency towards a normalization at two years of age. At four years of age there were no Group I infants with PMD; whereas, an increased rate of PMD was found in Group II infants.

Although fetal acidosis is related to a somewhat higher risk of handicap related problems at four years of age, in the very premature births of babies in Group I ( 4 of 7 with fetal acidosis vs. 1 of 6 without fetal acidosis, table II) this does

Table VI. Neurodevelopmental outcome at 4 years of age.

\begin{tabular}{|c|c|c|c|c|c|c|}
\hline & \multicolumn{3}{|c|}{ Sensory disorder } & \multicolumn{3}{|c|}{ Neurodevelopmental disorders } \\
\hline & Sight & Hearing & Speech & Minor & Major & Total \\
\hline $\begin{array}{l}\text { Group I } \\
\mathrm{n}=13\end{array}$ & 3 & 2 & 1 & 0 & 3 & $5 / 13(38.5 \%)$ \\
\hline $\begin{array}{l}\text { Group II } \\
\mathrm{n}=22\end{array}$ & 4 & 0 & 5 & 6 & 1 & $9 / 22(40.9 \%)$ \\
\hline $\begin{array}{l}\text { Control } \\
\mathrm{n}=10\end{array}$ & 0 & 0 & 1 & 0 & 0 & $1 / 10(10 \%)$ \\
\hline Total & 7 & 2 & 7 & 6 & 4 & \\
\hline
\end{tabular}




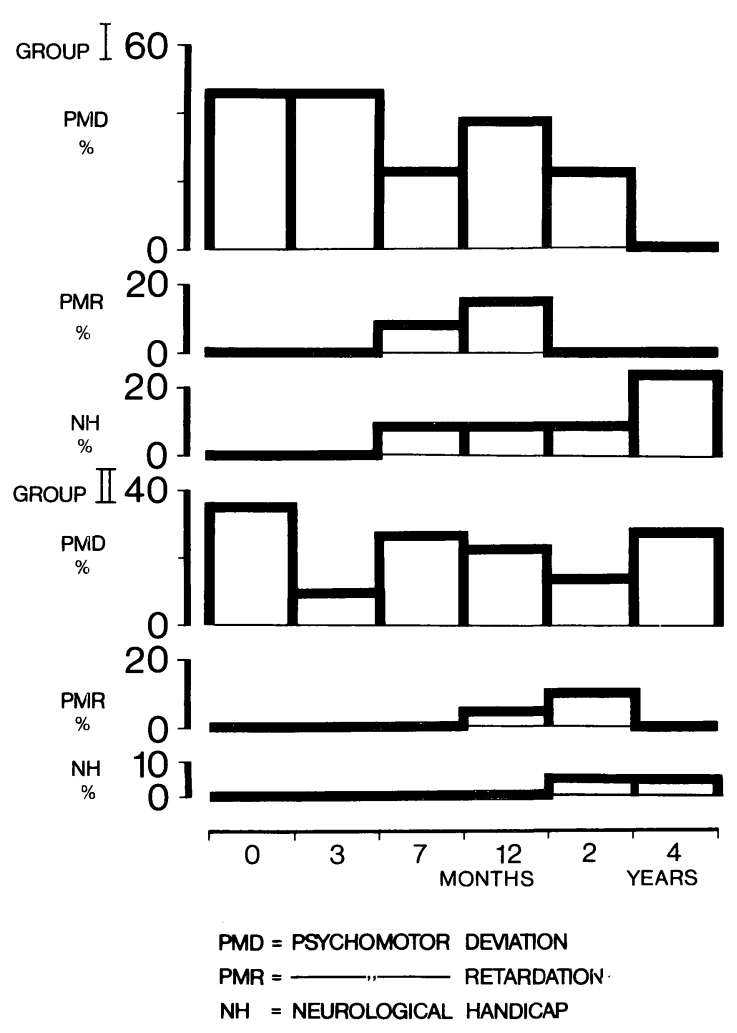

Figure 2. Longitudinal neurodevelopmental observations in Group I (29-33 gestational weeks) and Group II (34-36 gestational weeks) preterm infants.

PMD = Psychomotor deviation, PMR = Psychomotor retardation, $\mathrm{NH}=$ Neurological handicap (cerebral palsy or neuromuscular disorder).

not imply that infants without fetal acidosis can remain free from the risk of problems, since one of two with fetal acidosis and 8 of 20 without fetal acidosis in the only moderately preterm infants (Group II) still had problems at four years of age.

\section{Discussion}

Previous reports show that preterm infants on an average do less well in developmental tests, including speech disorders, and they also start to walk at a later age $[1,2,4,8,19,23]$. However, with a correction of the conceptual age, both preterm groups had a strong tendency towards normalization found in the results of their psychological tests. The value of using a corrected age has been questioned [6, 15, 17]. Perhaps a correction in some aspects balances preterm and term infants, but in others disguises behavioral problems diagnosed later as minor behavioral psychomotor deviations (PMD) $[6,23]$. Further, longitudinal investigations on selected and well defined populations are needed.

Early immediate separation of mother and child has been correlated to later psychosocial problems by some investigators and rejected by others with referrence to other periods in early human life to be just as important for later development [7, 13, 22]. A more intimate contact between mother and infant was postponed in our study for approximately 45 minutes. The repeated psychosocial interviews showed a well functioning mother to child contact, established within the first days in all but two months. All mothers were taking an early and active part in the day-to-day nursing care which might be as important for the imprinting of a parentinfant attachment necessary for later favorable development as the immediate contact after birth probably is $[12,15]$.

Recent studies show a decrease in major neurologic handicap and psychomotor retardation (PMR) in a growing number of preterm infants who survived neonatal care $[6,11,21]$. In this low risk population with neither intrapartum nor postpartum explanation for later poor psychomotor outcome, there was a tendency of normalization at two years of age in both preterm groups. At four years of age, more speech disorders and neurodevelopmental problems were found in the moderately preterm infants (Group II) in comparison to term control infants. This points to the need of psychological and neurodevelopmental follow-up, including hearing and vision tests, not only in the smallest infants, but also in moderately preterm infants. This has also been observed by HAGBERG et al. $[10,11]$, who observed a certain increase of cerebral palsy in later years in infants with birthweights between $2000-2500 \mathrm{~g}$. 
In this study the mortality rate did not differ between the two preterm low risk preganancy groups, although an acidotic fetal scalp $\mathrm{pH}$ below 7.20 was found in $52 \%$ Group I infants compared to $12 \%$ Group II infants. The Apgar score at five minutes was normally in all infants. Normalization of the $\mathrm{pH}$ at 60 minutes of age could be indicative of the ability of modern peri- and neonatal programs to stabilize the preterm infants rapidly after birth. This is probably most important for their survival and neurodevelopmental results $[12,13]$.

This study shows a rise in minor (PMD) problems with a shifting longitudinal trend over the four-year study. The neurological symptoms were mild in most infants, and no infant presented signs of mental retardation at the physical and behavioral examination at four years of age. This is probably due to the effect of excluding high risk pregnancies. A continuing decrease of minor psychomotor deviations was found in Group I but not in Group II infants during the four years studied. The proportion of infants of moderate prematurity (Group II), with some problems at four years of age, was similar in the groups with or without fetal acidosis in contrast to the very preterm infants (Group I) with a higher handicap rate after fetal acidosis [24]. Risk factors have been studied to calculate the risk of later handicap but they are very difficult to interpret $[11,14,18]$. The most reliable way to deal with infants at risk thus remains as a longitudinal individual follow-up of the preterm infant at general health centers or follow-up clinics [14].

While long term follow-up efforts at present concentrate on very preterm survivors after complicated deliveries, the moderately preterm infants should not be forgotten. Such infants with only small neurodevelopmental abnormalities may, later in childhood, benefit more from a psychological and neurodevelopmental follow-up at an age when more reliable tests for the detection of minor deviations can be performed. Consequently the children in the present study will be re-evaluated at school age with Griffith developmental test.

\section{Summary}

A prospective follow-up study of 39 vaginally born low risk preterm $(<37$ weeks of gestation) and ten term control infants was carried out to estimate psychological and neurodevelopmental outcome at four years of age in relation to conceptual age and fetal acidosis at birth. The patients were divided into two groups: infants born after 29-33 weeks gestation (Group I) and those born after 34-36 weeks gestation (Group II), with or without fetal acidosis, i.e. a fetal scalp $\mathrm{pH}$ below or above 7.20. Acidotic infants normalized within the first hour after birth. Marked low and high performance groups

for intellectual performance and hearing and vision tests were discernable within the first two years. The language performance of preterm infants was delayed compared to infants born at term, especially in Group II infants. At four years of age, a higher number of Group II infants had psychomotor developmental problems; whereas, neurological handicaps were more frequent in Group I infants with fetal acidosis. This indicates that re-evaluation of neurodevelopmental outcome is needed at a later age, e.g. six years of age, in preterm infants after low risk deliveries.

Keywords: Longitudinal follow-up, low risk prematurity, neurodevelopmental outcome, psychological testing.

\section{Zusammenfassung}

Vaginal entbundene Frühgeborene ohne zusätzliche Risikofaktoren: psychischer und neurologischer Entwicklungsstand bei Nachuntersuchungen in einem Zeitraum von 4 Jahren

In einer prospektiven Studie wurden bei 39 vaginal entbundenen Frühgeborenen $(<37$ Schwangerschaftswochen ohne zusätzliche Risikofaktoren) und $10 \mathrm{am}$ Termin geborenen Kontrollkindern im Alter von 4 Jahren

Nachuntersuchungen durchgeführt. Uns interessierte der psychische und neurologische Entwicklungsstand unter Berücksichtigung des Konzeptionsalters und einer fetalen Azidose zum Zeitpunkt der Geburt. Es wurden zwei Gruppen gebildet: Gruppe I umfaßte Kinder der 29. - 33. Woche nach Konzeption, Gruppe II Kinder der 34. - 36. Woche nach Konzeption. Eine weitere Unterteilung berücksichtigte das Auftreten einer fetalen Azidose 
(pH im Skalpblut unter 7.20), wobei sich azidotische Kinder innerhalb der ersten Lebensstunde normalisiert hatten. Hinsichtlich der intellektuellen Leistung sowie nach Hör- und Sehtests konnten innerhalb der ersten beiden Lebensjahre Kinder mit extrem hohem Entwicklungsstand von solchen mit niedrigem Entwicklungsstand unterschieden werden. Das Einsetzen sprachlicher Fähigkeiten war bei Frühgeborenen, speziell aus der Gruppe II, im Vergleich zu Reifgeborenen verzögert. Im
Alter von 4 Jahren hatte eine größere Anzahl von Kindern aus der Gruppe II psychomotorische Entwicklungsstörungen, während neurologische Auffälligkeiten häufiger bei Kindern aus der Gruppe I mit fetaler Azidose gefunden wurden. Wir meinen, da $B$ bei Frühgeborenen ohne zusätzliche Risikofaktoren eine erneute Untersuchung des neurologischen Entwicklungsstandes zu einem späteren Zeitpunkt, z. B. mit 6 Jahren, angezeigt ist.

Schlüsselwörter: Frühgeborene ohne zusätzliche Risikofaktoren, Langzeitstudien, neurologischer Entwicklungsstand, psychologischer Test.

\section{Résumé}

\section{Enfants nés par voie vasse prématurément lors de gros- sesse à bas risque: étude de la surveillance psychologique et du développement neurologique sur quatre ans}

On a réalisé une étude prospective de la surveillance de 39 enfants nés par voie basse prématurément $(<37$ semaines de gestation) lors de grossesse à bas risques et de 10 enfants contrôles nés à terme, afin d'estimer le devenir psychologique et du développement neurologique à l'âge de quatre ans en relation avec l'âge gestationnel et l'acidose fotale à la naissance. Le matériel a été subdivisé en deux groupes: les enfants nés après $29-33$ semaines (groupe I) et après $34-36$ semaines (groupe II), avec ou sans acidose fotale c'est-à-dire avec un $\mathrm{pH}$ fœtal au scalp au-dessous ou au-dessus de 7,20. Les enfants nés en état d'acidose sont normalisés au cours de la première heure après la naissance. Dans les deux premières années, on a pu distinguer des groupes extrêmes à basses et hautes performances en ce qui concerne les aspects intellectuels et les tests d'audition et de vision. Le langage des enfants prématurés a été retardé en comparison des enfants nés à terme, tout particulièrement chez les enfants du groupe II. A l'âge de quatre ans, un nombre élevé d'enfants du groupe II a des problèmes de développement psycho-moteur, tandis que ce sont les handicaps neurologiques qui sont plus fréquents chez les enfants du groupe I avec acidose fætale. Cela indique qu'il est necessaire de refaire une évaluation du devenir du développement neurologique à un âge plus tardif, par exemple, à l'âge de six ans, chez les enfants prématurés après des grossesses à bas risque.

Mots-clés: Prématurité à bas risque, test psychologique, développement neurologique, suivi longitudinal.

\section{References}

[1] ALI Z, M LOWRY: Early maternal child contact. Effects on later behavior. Dev Med Child Neurol 23 (1981) 337

[2] Bhattacharya I, MI BenNett, SM Tucker: Long term follow-up of newborns tested with the auditory response cradle. Arch Dis Childh 59 (1984) 504

[3] Catell P: The measurements of intelligence of infants and young children. The Psychological Corporation, New York 1960

[4] Chaplais I De Z, IA MacFarlane: A review of 404 'late walkers'. Arch Dis Childh 59 (1984) 512

[5] Davies PA: Perinatal mortality. Arch Dis Childh 55 (1980) 833

[6] DavIES PA: Follow-up of low birthweight children. Arch Dis Childh 59 (1984) 794

[7] Chateau P DE: Parent-infant interaction and its long term effects. In: Simmel E (ed): Early experiences and early behavior: Implications for social development, pp 109. Academic Press Inc, New York 1980
[8] Ferrari F, M Grosoli, G Fontana, G Cavazzuti: Neurobehavioral comparison of low-risk preterm and fullterm infants at term conceptual age. Dev Med Child Neurol 25 (1983) 450

[9] Frankenburg WK, JB Dodds: The Denver developmental screening test. J Pediatr 71 (1967) 181

[10] Hagberg B, G HAGBerg, I Olow: Gains and hazards of intensive neonatal care: an analysis from Swedish cerebral palsy epidemiology. Dev Med Child Neurol 24 (1982) 13

[11] Hagberg B, G Hagberg, I Olow: The changing panorama of cerebral palsy in Sweden IV. Epidemiologic trends 1959-78. Acta Paediatr Scand 73 (1984) 433

[12] JefFCOATE JA, ME Humphrey, JK Lloyd: Disturbance in parent-child relationship following preterm delivery. Dev Med Child Neurol 21 (1979) 344

[13] Klaus M, J KenNell: Interventions in the premature nursery: Impact of development. In: Symposium on the Newborn. Ped Clin N Am 29 (1982) 1266 
[14] KöHLER L, NN SveNNINGSEN, B LINDQUIST: Early detection of preschool problems - role of perinatal risk factors. Acta Paediatr Scand 79 (1979) 229

[15] LASKY RE, JE TYSON, CR ROSENFELD, NF GANT: Maternal-infant interactions at one-year adjusted age in infants at low- and high-risk as newborns. Early Hum Dev 9 (1984) 145

[16] Milani-CompareTti A, ER Gidoni: Routine developmental examination in normal and retarded children. Dev Med Child Neurol 9 (1967) 631

[17] Miller G, L Dubowitz, P Palmer: Follow-up of preterm infants: is correction of the developmental quotient for prematurity helpful? Early Hum Dev 9 (1984) 137

[18] Minde K, A Whitelaw, J Brown, P FitzharDINGE: Effect of neonatal complications in premature infants on early parent-infant interactions. Dev Med Child Neurol 25 (1983) 763

[19] Palmer PG, LMS Dubowitz, M Verghote, V DuBOWITZ: Neurological and neurobehavioral differences between preterm infants at term and full-term newborn infants. Neuropediatrics 13 (1982) 183
[20] STEnSLAND IK: Selective attention in infants and consecutive communicative behavior. Almqvist/ Wiksell, Stockholm 1972

[21] Stewart AL, EOR Reynolds, AP LiPSCOMB: Outcome for infants of very low birthweight: survey of world literature. Lancet I (1981) 1938

[22] SIEGEL E: Early and extended maternal-infant contact. Am J Dis Child 136 (1982) 251

[23] Silva PA, R McGee, SM Williams: Developmental language delay from three to seven years and its significance for low intelligence and reading difficulties at age seven. Dev Med Child Neurol 25 (1983) 783

[24] Westgren M, P Holmovist, NW Svenningsen, I INGEMARSSON: Intrapartum fetal monitoring in preterm deliveries. Prospective study. Obstet Gynecol 60 (1982) 99

Received September 4, 1985. Revised February 14, 1986. Accepted February 26, 1986.

Peter Holmqvist, M. D.

Department of Pediatrics University Hospital S-221 85 Lund Sweden 